\title{
Rapid detection of Salmonella in food and beverage samples by polymerase chain reaction
}

\author{
Radji, M., ${ }^{*}$ Malik, A. and Widyasmara, A. \\ Laboratory of Microbiology and Biotechnology, Department of Pharmacy, \\ Faculty of Mathematics and Sciences, University of Indonesia, Kampus UI, Depok, 16424, Indonesia. \\ E-mail: maksum@farmasi.ui.ac.id
}

Received 29 June 2009; received in revised form 30 September 2009; accepted 22 January 2010

\begin{abstract}
Polymerase chain reaction (PCR) assay had been used to detect Salmonella in food and beverage samples using suitable primers which are based on specific invA gene of Salmonella. Twenty nine samples were collected from street food counters and some canteens in Margonda Street, Depok, West Java, Indonesia. It was found that five of twenty nine samples were detected to contain Salmonella and showed the presence of the amplified product of the size $244 \mathrm{bp}$. The method of PCR demonstrated the specificity of invA primers for detection of Salmonella as confirmed by biochemical and serological assay. The results of this study revealed that PCR was a rapid and useful tool for detection of Salmonella in food and beverage samples.
\end{abstract}

Keywords: Salmonella, PCR, primer, invA

\section{INTRODUCTION}

Typhoid fever, also known as enteric fever occurs worldwide, primarily in developing countries, including Indonesia. Typhoid fever is a systemic infection caused primarily by Salmonella serotype Typhi. The disease remains an important public health problem in developing countries. In 2000, it was estimated that over 2.16 million episodes of typhoid occurred worldwide, resulting in 216,000 deaths and that more than $90 \%$ of this morbidity and mortality occurred in Asia (Crump et al., 2004). In Indonesia, the incidence of typhoid was 148.7 per 100,000 person-years (Ochiai et al., 2008).

The transmission of typhoid fever occurs by oral transmission via food or beverages handled by an individual who chronically sheds the bacteria through stool and via sewage-contaminated water sources which could possibly be due to fecal contamination from human and animal. The unsanitary practices of food and beverages processes lead to contamination of foods by Salmonella. The previous study showed that $25 \%-50 \%$ of beverage samples which are sold on the street food counters in Bogor, Indonesia, were contaminated predominantly by Salmonella paratyphi A. The contamination of bacteria possibly comes from the uncooked water (Anita, 2002).

The increased frequency of food-borne Salmonella has been causing recurring outbreaks, sometime with fatal infections. The exceedingly variable manifestations of typhoid fever have lead to the development of numerous diagnostic techniques. The routine detection of Salmonella in the environment including in foods and beverages is a necessary component of public health programs.
Standard cultural methods for detection of Salmonella are sensitive enough to detect Salmonella in food samples. However, the cultural methods also require multiple sub-culturing stages followed by biochemical and serological confirmatory tests with can take up to seven days to get a confirmed positive result. Therefore, these methods may be too time-consuming in cases where rapid pathogen identification is critical. In addition, sensitivity of cultures can be affected by antibiotic treatment, inadequate sampling, variations of bacteremia and a small number of viable organisms in samples (Miller and Pegues, 2000).

The development of molecular methods for diagnosis of infectious diseases has improved the sensitivity, specificity, quality and availability of diagnosis and treatment. Several polymerase chain reaction (PCR) assays for detection of Salmonella have been developed, and different targets DNAs for amplification have been applied. PCR enables the detection of Salmonella in different sources, such as human or animal feces (Stone et al., 1994; Juck et al., 1996), soil (Way et al., 1993), environmental water samples and other sources (Way et al., 1993; Pathmanathan et al., 2003; Aurélie et al., 2005).

PCR studies have also been carried out to evaluate the specificity of invA primers to detect Salmonella by PCR technique (Chiu and Ou, 1996; Jenikova et al., 2000; Carli et al., 2001; Gentry-Weeks et al., 2002; Ziemer and Steadham, 2003; Moganedi et al., 2007). The oligonucleotide primer pairs were developed according to the sequences of the chromosomal invA gene (Chiu and Ou, 1996), which is essential in the invasion of Salmonella to enter the epithelial cells (Galan et al., 1992). Rahn et al. (1992) reported that the invA primers were able to 
discriminate between Salmonella and non-Salmonella species. The detection limit was $300 \mathrm{cfu} / \mathrm{mL}$ of pure culture, however they did not evaluate the methods on environmental samples. Moganedi et al. (2007) demonstrated that the inv $A$ primers were specific for the detection of Salmonella in drinking and surface waters and the limit of detection of PCR was $2.6 \times 10^{4} \mathrm{cfu} / \mathrm{mL}$. PCR analysis offers several advantages including the specificity and rapidity. In order to develop the simple and rapid method for detection of Salmonella, in this study we used the invA1 and invA2 primers to detect Salmonella in food and beverage samples which were collected from street food counters and some canteens in Margonda Street, Depok, West Java, Indonesia.

\section{MATERIALS AND METHODS}

\section{Food and beverage samples}

Twenty nine food and beverage samples were collected from street food counters and some canteens in Margonda Street, Depok, West Java, Indonesia. The samples were selected for the possibility of contamination of Salmonella during the handling, processing and storage of raw material of the foods and beverages. All samples that were labeled and recorded have to be analyzed as soon as possible. Samples can be refrigerated on $0-4{ }^{\circ} \mathrm{C}$ for not more than $24 \mathrm{~h}$ after collection. The pre-enrichment of samples was performed according to the method described by Medici et al. (2003) with some modification. Briefly, $25 \mathrm{~g}$ or $25 \mathrm{~mL}$ samples were homogenized with $225 \mathrm{~mL}$ of Buffered Peptone Water medium and incubated at $37{ }^{\circ} \mathrm{C}$ for $24 \mathrm{~h}$. The pre-enrichment culture was then divided into two aliquots. The first aliquot was subjected to DNA extraction by boiling method and the second aliquot was used to confirm the presence of Salmonella by standard cultural method, and followed by biochemical and serological confirmatory tests.

\section{Preparation of template DNA samples for PCR by boiling method}

Preparation of template DNA samples was performed by boiling method according to the method described by Medici et al. (2003). Briefly, $1 \mathrm{~mL}$ of the pre-enriched sample was transferred to a $1.5 \mathrm{~mL}$ micro-centrifuge tube and centrifuged for $10 \mathrm{~min}$ at $14,000 \times \mathrm{g}$. The supernatant was discarded carefully. The pellet was resuspended in $300 \mu \mathrm{L}$ of DNase-RNase-free distilled water (Sigma) by vortexing. The tube was centrifuged at $14,000 \times g$ for 5 min, and the supernatant was discarded carefully. The pellet was re-suspended in $200 \mu \mathrm{L}$ of DNase-RNase-free distilled water (Sigma) by vortexing. The micro-centrifuge tube was incubated for $15 \mathrm{~min}$ at $100{ }^{\circ} \mathrm{C}$ and immediately chilled on ice. The tube was centrifuged for $5 \mathrm{~min}$ at $14,000 \times g$ at $4{ }^{\circ} \mathrm{C}$. The supernatant was carefully transferred to a new micro-centrifuge tube and an aliquot of $10 \mu \mathrm{L}$ of the supernatant was used as the template DNA in the PCR.

\section{Preparation of template DNA Salmonella typhi as a positive control}

Salmonella typhi that was used as a positive control provided by Laboratory of Microbiology and Biotechnology, Department Pharmacy, Faculty of Mathematics and Sciences, University of Indonesia. DNA template of Salmonella typhi was prepared by a modified method of Murray and Thompson (1980), using cetyltrimethylammonium bromide (CTAB). Briefly, $5 \mathrm{~mL}$ of an overnight culture grown in LB broth culture was harvested by centrifugation. The pellet was resuspensed in STET buffer (sucrose, Tris base, ethylene diamine tetra acetic acid/EDTA, Triton X-100), $10 \mu \mathrm{L}$ lysozyme (concentration $10 \mathrm{mg} / \mathrm{mL}$; Sigma), $30 \mu \mathrm{L} 10 \%$ sodium dodesil sulphate (SDS; Sigma), and $4 \mu \mathrm{L}$ proteinase-K. The mixture was incubated at $37^{\circ} \mathrm{C}$ for $60 \mathrm{~min}$. After incubation, $65 \mu \mathrm{L} 4 \mathrm{M} \mathrm{NaCl}$ and $80 \mu \mathrm{L}$ CTAB were added and incubated at $65^{\circ} \mathrm{C}$ for $30-60 \mathrm{~min}$. DNA was purified by extraction with $624 \mu \mathrm{L}$ chloroform and $26 \mu \mathrm{L}$ isoamyl alcohol $(24: 1, v / v)$, and the nucleic acid was then pelleted by centrifugation, washed with $70 \%$ ethanol and dried under vacuum. The DNA pellet was resuspended in TE buffer (10 mM Tris/ $\mathrm{HCl}, \mathrm{pH} 7.5,0.1 \mathrm{mM}$ EDTA) and quantified by UV spectrophotometry at 260 and $280 \mathrm{~nm}$. Tenfold serial dilution with sterile distilled water were performed and $5 \mu \Lambda(0.25 \mu \mathrm{g})$ of DNA suspension was used as DNA template and then subjected to PCR amplification.

\section{Primers}

The sequences of the primer pairs used for DNA amplification of invA gene region of Salmonella were prepared according to Chiu and Ou (1996): invA1 (forward): ACA GTG CTC GTT TAC GAC CTG AAT (AIT Biotech) and invA2 (reverse): AGA CGA CTG GTA CTG ATC GAT AAT (AIT Biotech).

\section{PCR Protocol}

PCR was carried out according to Chiu and Ou (1996) in a programmable thermal controller (MJ Mini Biorad). PCR reaction mixture $(25 \mu \mathrm{L})$ contained $10 \mu \mathrm{L}$ template DNA, $12.5 \mu \mathrm{L}$ PCR Master Mix (PCR Buffer, $4 \mathrm{mM} \mathrm{MgCl}, 0.4$ $\mathrm{mM}$ of each dNTP, $1.25 \cup$ Taq polymerase; Fermentas), 1 $\mu \mathrm{M}$ of each primer and $\mathrm{ddH}_{2} \mathrm{O}$ to the total volume of $25 \mu \mathrm{L}$. The PCR was performed using the following condition: denaturation at $94{ }^{\circ} \mathrm{C}$ for $30 \mathrm{~s}$, primer annealing at $56{ }^{\circ} \mathrm{C}$ for $30 \mathrm{~s}$, and extension at $72{ }^{\circ} \mathrm{C}$ for 2 min for a total 30 cycles and a final extension step at $72{ }^{\circ} \mathrm{C}$ for $10 \mathrm{~min}$.

PCR amplicons were electrophoresed in a $2 \%$ agarose gel. After staining with ethidium bromide, the amplified fragments in the gel were visualized. The molecular mass marker used was $1 \mathrm{~kb}$ plus DNA ladder marker (Invitrogen). PCR was carried out in duplicate for each sample. One positive control (DNA from Salmonella typhi) and negative control were included. A product of 244 bp was considered the invA gene (Chiu and Ou, 1996). 


\section{Limit of PCR detection}

An overnight culture of Salmonella typhi was serially diluted 10 -fold with nutrient broth. A $1 \mathrm{~mL}$ aliquot of each dilution was centrifuged $(10,000 \times g)$ for $5 \mathrm{~min}$. The supernatant was discarded carefully. The pellets of bacteria were washed with $\mathrm{ddH}_{2} \mathrm{O}$ and finally re-

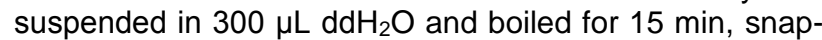
cooled on ice and then centrifuged at $14,000 \times g$ for 5 min at $4{ }^{\circ} \mathrm{C}$. After centrifugation, $10 \mu \mathrm{L}$ of supernatant were used as template in the PCR. Viable counts were obtained by plating $1 \mathrm{~mL}$ of each dilution of bacterial culture on nutrient agar plates and incubating overnight at $37^{\circ} \mathrm{C}$.

\section{Spiked food sample}

Spiking of food sample was performed according to Pathmanathan et al., (2003) with some modification. Briefly, $25 \mathrm{mg}$ of food sample free from Salmonella was homogenized with $225 \mathrm{~mL}$ Buffered Peptone Water medium and incubated for $24 \mathrm{~h}$ at $37^{\circ} \mathrm{C}$. The preenrichment broth was then divided into two aliquots: (a) the first aliquot was used as a negative control; (b) the second aliquot was spiked with an appropriate quantity of Salmonella typhi suspension to obtain a final concentration from $10 \mathrm{cfu} / \mathrm{mL}$ to $10^{9} \mathrm{cfu} / \mathrm{mL}$. The cell suspension were then centrifuged $(10,000 \times \mathrm{g})$ for $5 \mathrm{~min}$. The pellets of bacteria were washed with $\mathrm{ddH}_{2} \mathrm{O}$ and finally re-suspended in $300 \mu \mathrm{L} \mathrm{ddH}_{2} \mathrm{O}$ and boiled for 15 min, chilled on ice and then centrifuged at 14,000 $\times \mathrm{g}$ for 5 $\min$ at $4{ }^{\circ} \mathrm{C}$. After centrifugation, $10 \mu \mathrm{L}$ of supernatant were used as template in the PCR.

\section{Standard cultural method}

Twenty five $\mathrm{mg}$ or $25 \mathrm{~mL}$ samples were homogenized with $225 \mathrm{~mL}$ buffered peptone water medium and incubated for $18-24 \mathrm{~h}$ at $37^{\circ} \mathrm{C}$. After incubation, $1 \mathrm{~mL}$ of pre-enrichment broth culture were transferred to $9 \mathrm{~mL}$ of selenite cystein enrichment broth culture and incubated at $37^{\circ} \mathrm{C}$ for $24 \mathrm{~h}$. A loop from each of cultures was streaked onto a plate salmonella-shigella agar (SSA) and incubated at $37^{\circ} \mathrm{C}$ for 24 h. Presumptive Salmonella colonies were characterized by biochemical assay using lactose, glucose, and sucrose culture, triple sugar iron agar and urea agar media.

\section{Serological test}

Serological testing of samples was performed using the Salmonella test kit (Oxoid). Briefly, $25 \mathrm{mg}$ or $25 \mathrm{~mL}$ samples were homogenized with $225 \mathrm{~mL}$ buffered peptone water medium and incubated for $18-24 \mathrm{~h}$ at $37^{\circ} \mathrm{C}$ After incubation, $1 \mathrm{~mL}$ of pre-enrichment broth culture were transferred to $9 \mathrm{~mL}$ of selenite cystein enrichment broth culture and incubated at $37^{\circ} \mathrm{C}$ for $24 \mathrm{~h}$. One drop of the selenite cystein enrichment broth culture using a Pasteur pipette were dropped within one circle on the reaction card and mixed with 1 drop of the Oxoid
Salmonella Latex Reagent to the broth on the card. The suspension was mixed thoroughly using a clean mixing stick or inoculating loop, and then rocked the reaction card gently for 2 or 3 times. The agglutination was examined within a maximum of 2 min.

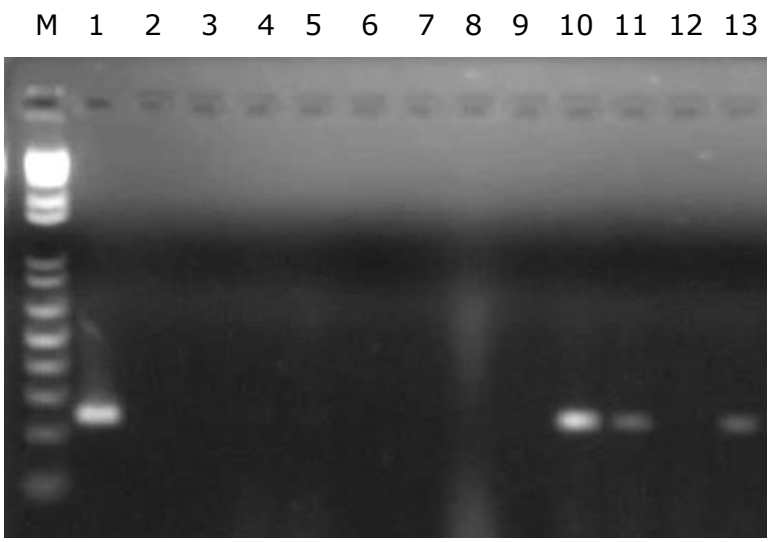

Figure 1: Representative samples determined by PCR and detected by $2 \%$ agarose gel electrophoresis. Lane $\mathrm{M}$ : $1 \mathrm{~kb}$ molecular size marker ladder; lane 1: positive control (Salmonella typhi); lanes $2-9$ and 12: negative samples; lanes 10, 11 and 13: positive samples

\section{RESULTS AND DISCUSSION}

The invA gene primer pair specific for Salmonella was used in PCR reaction on both the genomic DNA isolated from samples and on the genomic DNA isolated from pure cultures of Salmonella typhi produced an intense band of the expected $244 \mathrm{bp}$. In this study we found that the limit of detection of PCR using genomic DNA obtained by boiling method from pure cultures of Salmonella typhi and in the Salmonella-spiked food samples was $2.85 \times 104$ $\mathrm{cfu} / \mathrm{mL}$ and $2.85 \times 105 \mathrm{cfu} / \mathrm{mL}$ respectively (data not shown). Therefore the pre-enrichment samples in nonselective medium is a necessary step to increase the number of Salmonella in food and beverage samples. Similar results have reported previously that at least 103 105 cells/mL must be present to give positive results by PCR without a pre-enrichment step (Pathmanathan et al., 2003; Oliviera et al., 2003; Myint et al., 2006; Moganedi et al., 2007). Pre-enrichment culture has been done in order to increase the viable number of Salmonella in the samples prior to the detection of Salmonella by PCR technique. Boiling method was selected for preparation of the DNA template, because this method was simple and rapid to extract DNA. Centrifugation and washing steps were sufficient to remove the PCR inhibitors from culture medium. Boiling of the bacterial cells and then immediately cooling them on ice was efficient for releasing and denaturing the DNA template, resulting the suspension was directly subjected to the PCR without DNA isolation and purification steps (Herich et al., 2004). 
Table 1: Food and beverage samples tested for Salmonella by PCR, biochemical and serological assay

\begin{tabular}{|c|c|c|}
\hline Samples & PCR assay & $\begin{array}{l}\text { Biochemical and } \\
\text { Serological assay }\end{array}$ \\
\hline Fruits salad & $\mathrm{N}$ & $\mathrm{N}$ \\
\hline Fruits salad & $\mathrm{N}$ & $\mathrm{N}$ \\
\hline Fruits & $\mathrm{N}$ & $\mathrm{N}$ \\
\hline Fruits & $\mathrm{N}$ & $\mathrm{N}$ \\
\hline Cooked vegetables salad & $\mathrm{N}$ & $\mathrm{N}$ \\
\hline Vegetables salad & $\mathrm{N}$ & $\mathrm{N}$ \\
\hline Mixed vegetables salad & $\mathrm{N}$ & $\mathrm{N}$ \\
\hline Vegetables salad & $\mathrm{N}$ & $\mathrm{N}$ \\
\hline Coconut juice & positive & positive \\
\hline Coconut juice & $\mathrm{N}$ & $\mathrm{N}$ \\
\hline Coconut juice & positive & positive \\
\hline Ice Fruits cocktail & positive & positive \\
\hline Mixed cold drink & $\mathrm{N}$ & $\mathrm{N}$ \\
\hline Traditional cold drink & $\mathrm{N}$ & $\mathrm{N}$ \\
\hline Traditional cold drink & $\mathrm{N}$ & $\mathrm{N}$ \\
\hline Coconut juice & $\mathrm{N}$ & $\mathrm{N}$ \\
\hline Traditional cold drink & positive & positive \\
\hline Ice tea & $\mathrm{N}$ & $\mathrm{N}$ \\
\hline Mixed herbal cocktail & $\mathrm{N}$ & $\mathrm{N}$ \\
\hline Mixed herbal cocktail & $\mathrm{N}$ & $\mathrm{N}$ \\
\hline Coconut juice & $\mathrm{N}$ & $\mathrm{N}$ \\
\hline Vegetables salad & positive & positive \\
\hline Mixed herbal cocktail & $\mathrm{N}$ & $\mathrm{N}$ \\
\hline Traditional cold drink & $\mathrm{N}$ & $\mathrm{N}$ \\
\hline Cooked vegetables salad & $\mathrm{N}$ & $\mathrm{N}$ \\
\hline Ice Fruits cocktail & $\mathrm{N}$ & $\mathrm{N}$ \\
\hline Coconut juice & $\mathrm{N}$ & $\mathrm{N}$ \\
\hline Mixed herbal cocktail & $\mathrm{N}$ & $\mathrm{N}$ \\
\hline Fruits salad & $\mathrm{N}$ & $\mathrm{N}$ \\
\hline
\end{tabular}

$\mathrm{N}$ : negative

Five out of twenty nine samples were detected to contain Salmonella and revealed the presence of the amplified product of the size 244 bp (Figure 1). No false positives or negatives for Salmonella were observed with PCR as confirmed by standard cultural and serological methods (Table 1). This result proved the specificity of PCR compared to the conventional culturing and serological method. All Salmonella carry the invA gene, which is not carried by any other bacterial species. Therefore if $244 \mathrm{bp}$ amplified product appeared in the PCR with the invA1 and invA2 primers it would indicate that the sample contains an invA gene of Salmonella (Chiu and Ou, 1996).

Traditional approaches for analysis of Salmonella has relied on cultural techniques and several selectivedifferential media have used for differentiation. However, biochemical analysis for an enzyme associated with the particular pathogenic trait could be cross reactive with other enteric bacteria. In addition, the cultural methods also require multiple sub-culturing stages followed by biochemical and serological confirmatory tests with can take up to 7 days to get a confirmed positive result. In contrast to the 7 days culture method, in this study, $24 \mathrm{~h}$ pre-enrichment-PCR assay using invA1 and invA2 primers, offer a rapid and good diagnostic tool for the routine monitoring for detection of Salmonella in food and beverage samples. The presence of Salmonella in foods and beverages could be due to several reasons such as contamination of raw material, poor hygienic conditions, contamination of water sources and unsanitary processes of foods and beverages.

The presence of Salmonella in foods beverages which are sold on the street food counters is an important environmental issue because of the health problems can be involved. 


\section{REFERENCES}

Anita, N. (2002). The Microbial assessment of beverages in the school canteens in Bogor, Indonesia. Bogor Institute of Agriculture. Indonesia.

Aurélie, T., Thierry, B., Barbara, P. and Fabienne, P. (2005). Detection of Salmonella in environmental water and sediment by a nested-multiplex polymerase chain reaction assay. Research in Microbiology 156, 541-553.

Carli, K. T., Unal, C. B., Caner, V. and Eyigor, A. (2001). Detection of Salmonellae in chicken feces by a combination of tetrathionate broth culture enrichment, capillary PCR and capillary gel electrophoresis. Journal of Clinical Microbiology 39, 1871-1876.

Crump, J. A., Luby, S. P. and Mintz, E. D. (2004). The global burden of typhoid fever. Bulletin of the World Health Organization 82, 346-353.

Chiu, C. H. and Ou, J. T. (1996). Rapid identification of Salmonella serovars in feces by specific detection of virulence genes, invA and spvC, by an enrichment broth culture culture-multiplex PCR combination assay. Journal of Clinical Microbiology 34, 2619-2622

Galan, J. E., Ginocchio, C. and Costeas, P. (1992). Molecular and functional characterization of Salmonella invasion gene InvA: Homology of InvA to members of a new protein family. Journal of Bacteriology 174, 4338-4349.

Gentry-Weeks, C., Hutcheson, H. J., Kim, L. M., Bolte, D., Traub-Dargatz, J., Morley, P., Powers, B. and Jessen, M. (2002). Identification of two phylogenetically related organisms from feces by PCR for detection of Salmonella spp. Journal of Clinical Microbiology 40, 1487-1492.

Herich, R., Laukova, A., Stompfova, V., Revejova, V., Levkut, M. and Pistl, J. (2004). Optimalization of Salmnoenella detection in chickens' caecum using PCR method. Archiv Tierzucht Dummerrstorf 47, 8591.

Jenikova, G., Pazlarova, J. and Demnerova, K. (2000). Detection of Salmonella in food samples by combination of separation and PCR assay. International Microbiology 3, 225-229.

Juck, D., Ingram, J., Prevost, M., Coallier, J. and Greer, C. (1996). Nested PCR protocol for the rapid detection of Escherichia coli in potable water. Canadian Journal of Microbiology 42, 862-866.

Medici, D. D., Croci, L., Delibato, E., Pasquale, S., Filetici, E. and Toti, L. (2003). Evaluation of DNA extraction methods for use in combination with SYBR Green I Real-Time PCR to detect Salmonella enteritica serotype enteritidis in poultry. Applied and Environmental Microbiology 69, 3456-3461.

Miller, S. and Pegues, D. (2000). Salmonella species, including Salmonella typhi. In: Mandell, Douglas and Bennett's Principles and Practice of Infectious Diseases. Mandell, G. L., Bennett, J. E. and Dolin, R. (eds.). $5^{\text {th }}$ edn. Churchill Livingstone, Philadelphia. pp. 2344-2363.
Moganedi, K. L. M., Goyvaerts, E. M. A., Venter, S. N., Sibara, M. M. (2007). Optimisation of the PCR-invA primers for the detection of Salmonella in drinking and surface waters following pre-cultivation step. Water SA 33, 196-202.

Murray, M. G. and Thompson, W. F. (1980). Rapid isolation of high molecular weight DNA. Nucleic Acids Research 8, 4321-4325.

Myint, M. S., Johnson, Y. T., Tablante, N. L. and Heckert R. A. (2006). The effect of pre-enrichment protocol on the sensitivity and specificity of PCR for detection of naturally contaminated Salmonella in raw poultry compared to conventional culture. Food Microbiology 23, 599-604

Ochiai, R. L., Acosta, C. J., Danovaro-Holliday, M. C., Baiqing, D., Bhattacharya, S. K., Agtini, M. D., Bhutta, Z. A., Canh, D. G., Ali, M., Shin, S., Wain, J., Page, A. L., Albert, M. J., Farrar, J., AbuElyazeed, R., Pang, T., Galindo, C. M., Seidlein L. V. and Clemens, J. D. (2008). A study of typhoid fever in five Asian countries: Disease burden and implications for controls. Bulletin of the World Health Organization 86, 241-320.

Oliviera, S. D., Rodenbushi, C. R., Ce, M. C., Rocha, S. L. and Canal, C. W. (2003). Evaluation of selective and non-selective enrichment PCR procedures for Salmonella detection. Letters in Applied Microbiology 36, 217-221.

Pathmanathan, S. G., Cardona-Castro, N., SánchezJiménez, M. M., Correa-Ochoa, M. M., Puthucheary, S. D. and Thong, K. L. (2003). Simple and rapid detection of Salmonella strains by direct PCR amplification of the hilA gene. Journal of Medicinal Microbiology 52, 773-776.

Rahn, K., De Grandis, S. A., Clarke, R. C., McEwen, S. A., Galan, J. E., Ginocchio, C., Curtiss, R. and Gyles, C. L. (1992). Amplification of an invA gene sequence of Salmonella typhimurium by polymerase chain reaction as a specific method of detection of Salmonella. Molecular and Cellular Probes 6, 271279.

Stone, G. G., Oberst, R. D., Hays, M. P., McVey, S. and Chengappa, M. M. (1994). Detection of Salmonella serovars from clinical samples by enrichment broth cultivation-PCR procedure. Journal of Clinical Microbiology 32, 1742-1749.

Ziemer, C. J. and Steadham, S. R. (2003). Evaluation of the specificity of Salmonella PCR primers using various intestinal bacterial species. Letters in Applied Microbiology 37, 463-469.

Way, J. S., Josephson, K. L., Pillai, S. D., Abbaszadegan, M., Gerba, C. P. and Pepper, I. L. (1993). Specific detection of Salmonella spp. by multiplex polymerase chain reaction. Applied and Environmental Microbiology 59, 1473-1479. 